\title{
PEMBELAJARAN BERBASIS PENDEKATAN RELIGIUS DALAM MENINGKATKAN AKHLAK DAN HASIL BELAJAR PESERTA DIDIK DI MADRASAH IBTIDAIYAH
}

\author{
Muhammad Arfah \\ MI Datok Pattimang Mario \\ Mario Kec. Ponrang kab. Luwu, Sulawesi Selatan \\ E-mail:m.arfah5321@gmail.com
}

\begin{abstract}
The purpose of this study to improve students' morality and learning outcomes through the application of religious approach based learning at MI Datok Pattimang Mario District. Ponrang. The formulation of the research problem is how the application of religious approach-based learning in improving students' morals and learning outcomes in MI Datok Pattimang Mario Kec. Ponrang. The type of research used is qualitative research, the approach used is the pedagogical approach. Data collection techniques through library research and field research, while data analysis is the presentation of data, and drawing conclusions. The results of the study show that: (1) Religious approach based learning in MI Datok Pattimang Mario District. Ponrang Kab. Luwu is carried out by linking and integrating religious values in the learning process in order to achieve learning goals in each learning content. (2) The steps of learning based on a religious approach in improving students' morals and learning outcomes at MI Datok Pattimang Mario Kec. Ponrang Kab. Luwu is carried out by inserting religious values starting with the initial activities, core activities, and closing activities of learning in the form of praying, storytelling, and question and answer activities with students, and (3) Learning constraints based on religious approaches in improving students' moral and learning outcomes in MI Datok Pattimang Mario Kec. Ponrang district. Luwu comes from students, educators and infrastructure facilities supporting the learning process.
\end{abstract}

Keywords: Learning Based on Religious Approach, Morals, and Learning Outcomes

\begin{abstract}
Abstrak
Tujuan penelitian ini untuk meningkatkan akhlak dan hasil belajar peserta didik melalui penerapan pembelajaran berbasis pendekatan religius di MI Datok Pattimang Mario Kec. Ponrang. Adapun rumusan masalah penelitian adalah Bagaimanakah penerapan pembelajaran berbasis pendekatan religius dalam meningkatkan akhlak dan hasil belajar peserta didik pada MI Datok Pattimang Mario Kec. Ponrang. Adapun jenis penelitian yang digunakan adalah penelitian kualitatif, Pendekatan yang digunakan pendekatan pedagogi. Teknik pengumpulan data melalui library research dan field research, sedangkan analisis data adalah penyajian data, dan penarikan kesimpulan. Hasil penelitian menunjukan bahwa: (1) Pembelajaran berbasis pendekatan religius di MI Datok Pattimang Mario Kec. Ponrang Kab. Luwu dilakukan dengan mengaitkan dan mengintegrasikan nilai-nilai religius dalam proses pembelajaran demi tercapainya tujuan pembelajaran pada tiap-tiap muatan pembelajaran. (2) Langkah-langkah pembelajaran berbasis pendekatan religius dalam meningkatkan akhlak dan hasil belajar peserta didik di MI Datok Pattimang Mario Kec. Ponrang Kab. Luwu dilakukan dengan menyisipkan nilai religius dimulai dengan kegiatan awal, kegiatan inti, dan kegiatan penutup pembelajaran berupa kegiatan berdoa, bercerita, dan tanya jawab dengan peserta didik, dan (3) Kendala pembelajaran berbasis pendekatan religius dalam meningkatkan akhlak dan hasil belajar peserta didik di MI Datok Pattimang Mario Kec. Ponrang kab. Luwu berasal dari siswa, pendidik dan sarana prasana pendukung proses pembelajaran.
\end{abstract}


Kata Kunci,: Pembelajaran Berbasis, Pendekatan Religius, Akhlak, dan Hasil Belajar.

\section{PENDAHULUAN}

Kemajuan suatu bangsa ditentukan dari kondisi sistem pendidikan yang diselenggarakannya. Peran pendidikan sangat mendukung untuk menciptakan kehidupan bangsa yang cerdas, kreatif, terampil, dan inovatif. Asas kebudayaan bangsa yang kompleks dan komunal merupakan pijakan inti susunan kehidupan (M. Tahir Sapsuha, 2013:10), menurut Evra, Pendidikan islam yang menjadi subsistem merupakan salah satu media yang efektif untuk melahirkan generasi yang memiliki pandangan yang dapat mengembangkan pendidikan kearah yang lebih baik. Oleh karena itu proses pembelajaran diharapkan dapat mempraktikan sikap terpuji disekolah maupun dimasyarakat luas (Evra et.al., 2018: 235). Tidak dapat dipungkiri lagi bahwa Pendidikan agama merupakan ujung tombak kesuksesan Pendidikan morak dan karakter. Penanaman karakter dapat diintegrasikan ke dalam kurikulum pembelajaran yang tercermin pada rencana pelaksanaan pembelajaran (Rustan, Hanifah, \& Kanro, 2018). Pemberian nilai-nilai agama di MI Datok Pattimang merupakan salah satu wujud dari kepedulian dalam membentuk moral dan akhlak siswa untuk lebih baik. Sebagai sekolah berbasis keagamaan guru-guru di MI Datok Pattimang dalam muatan pembelajaran apapun harus bisa mengkontekstualkan materi-materi pembelajaran dengan dalil-dalil, baik itu hadis nabi, maupun dari kitab al-qur'an demi terciptanya Pendidikan yang cita-citakan.

Namun Perkembangan zaman yang semakin maju dan berkembang menuntut Pendidikan agar lebih bisa beradaptasi dengan kondisi zaman yang semakin maju, Pendidikan harus memposisikan sebagai pondasi untuk membentuk karakter siswa yang lebih baik, Pendidikan yang dapat menyeimbangkan kognitif, afektif, dan psikomotirik siswa secara seimbang. Hal tersebutakan sulit terwujud jika dalam Pendidikan dewasa ini masih tidak ada perubahan skema pembelajaran yang dapat merubah Pendidikan saat ini.

Dalam bukunya, Ngainun Naim berpendapat bahwa kegagalan pendidikan ini disebabkan karena praktik pendidikannya hanya memperhatikan aspek kognitif semata dari pertumbuhan nilai-nilai (agama), mengabaikan pembinaan aspek afektif, dan psikomotorik (Ngainun Naim, 2011: 10). Sehingga hal tersebut berdampak pada krisis moral, dan akhlak (karakter) Pendidikan siswa, untuk menangkal hal tersebut, salah satu upaya yang dianggap ampuh yaitu melalui jalur Pendidikan terutama Pendidikan agama (Amos Neolaka, Grace Amalia A. Neolaka, 2017: 418).

Dewasa ini semakin terasa perlu manusia dibentengi dengan akhlak mulia dan Pendidikan moral serta nilai-nilai religius mengingat pengaruh PiJIES: Pedagogik Journal of Islamic Elementary School 
besar terhadap kehidupan manusia. Semakin tinggi keimanan dan ketakwaan seseorang maka akan semakin positif penghayatan seseorang dalam kehidupan sehari-hari yang tercermin dalam cara seseorang menghadapi berbagai persoalan (Thaha \& Rustan, 2017). Pendidikan moral adalah Pendidikan yang menyangkut pembinaan akhlak dan tingkah laku moral yang baik atau budi pekerti yang baik (Ani Nur Aeni, 2014: 38), sehingga dapat membentuk budi pekerti luhur, berakhlak mulia dan berprilaku terpuji, berkarakter yang baik seperti yang terdapat dalam Pancasila dan undangundang dasar 1945. Keberhasilan pembelajaran tidak lepas dari peran Guru yang senantiasa bekerja keras demi terwujudnya Pendidikan yang lebih baik (Darnia, 2019). Guru adalah ujung tombak pendidikan suatu bangsa, keberhasilan Pendidikan sangat ditentukan dari peran guru membangun komunikasi pembelajaran dengan anak didiknya. Guru juga sangat dituntut untuk senantiasa mengembangkan diri dan metode pembelajarannya dengan penggunaan cara yang paling tepat (Thalib, 2018). Seorang guru juga harus mampu melaksanakan tugasnya dalam beberapa peran yang berbeda ia tidak saja menjadi transfer ilmu melainkan harus mampu memainkan berbagai peran antara lain guru sebagai pemimpin kelas, pengatur lingkungan, partisipan, ekspidiator, perencana, supervisior, dan motivator dalam proses pembelajaran (Ahmad Izzan, et.al., 2012: 38-39).

Dalam proses pembelajaran, kepribadian seorang guru dituntut sebagai suri tauladan dalam proses pembelajaran dikelas, memberikan ruang kepada siswa dalam mengeluarkan buah pikiran, dan mengembangkan kreativitas siswa. Kepribadian yang harus ada pada diri guru yakni kepribadian yang mantap, stabil, dewasa, arif, dan beribawa, memnjadi teladan bagi siswa dan berakhlak mulia (Muhammad Anwar, 2018: 15).

Pendidikan akhlak mengarahkan siswa untuk berprilaku baik, adab istiadat merujuk kepada tingkah laku yang mantap dan keteladanan merujuk kepada kualitas karakter. Oleh karena itu sebagai seorang muslim yang baik diwajibkan untuk mengikuti keteladanan Nabi Muhammad saw., karena dalam pribadi Rasul, bersemai nilai-nilai akhlak yang mulia dan agung. Berikut firman Allah dalam QS. Al Ahzab: 21:



Terjemahnya:

Sesungguhnya telah ada pada (diri) Rasulullah itu suri teladan yang baik bagimu (yaitu) bagi orang yang mengharap (rahmat) Allah dan (kedatangan) hari kiamat dan dia banyak menyebut Allah. (Depertemen RI., 2015: 325). 
Nabi shallallahu alaihi wassallam bersabda:

Artinya

$$
\text { أكملُ المؤمنين إيمانًا أحسنُهم خُلقًا }
$$

Kaum mu'minin yang paling sempurna imannya adalah yang paling baik ahklaknya. (H.R. Tirmidzi No.1162, ia berkata hasan shahih)

Peran Guru dan orang tua haruslah senantiasa memberikan contohcontoh kepada siswanya tentang akhlak terpuji sesuai dengan apa yang dicontohkan oleh baginda rasullulloh saw., artinya Pendidikan religius tidak hanya diserahkan sepenuhnya pada sekolah sebagai lembaga pendidikan formal, akan tetapi diperlukan dukungan keluarga dan lingkungan masyarakat (Agus Zaenal Fitri, 2012: 21).

Sedangkan secara umum tujuan Pendidikan ini dalam keluarga adalah untuk membina anak-anak agar menjadi pribadi yang taat pada allah dan rasulnya, berbakti pada orang tuanya, bermanfaat untuk masyarakat, dan berguna bagi agama, nusa dan bangsa (Amirulloh Syarbini, 2014: 45).

Adapun maksud dan tujuan penelitian adalah 1) Untuk Mengetahui pembelajaran berbasis pendekatan religius dalam meningkatkan akhlak dan hasil belajar peserta didik pada MI Datok Pattimang Mario Kec. Ponrang Kab. Luwu. 2) Untuk Mengetahui langkah-langkah pembelajaran berbasis pendekatan religius dalam meningkatkan akhlak dan hasil belajar peserta didik pada MI Datok Pattimang Mario Kec. Ponrang Kab. Luwu. 3) Untuk Mengetahui kendala dalam pembelajaran berbasis pendekatan religius untuk meningkatkan akhlak dan hasil belajar peserta didik pada MI Datok Pattimang Mario Kec. Ponrang Kab. Luwu

\section{METODE PENELITIAN}

Jenis penelitian yang digunakan adalah penelitian kualitatif yang mengambarkan teknik-teknik spesifik dalam penelitian (Abdul Hakim, 2017: 27) Penelitian ini memberikan gambaran sistematis, cermat, dan akurat mengenai peran guru dalam meningkatkan akhlak serta hasil belajar peserta didik pada MI Datok Pattimang Mario Kec. Ponrang Kab. Luwu. Selanjutnya, data yang diperoleh dalam penelitian ini tidak berupa angka-angka, akan tetapi data yang dinyatakan secara deskriptif.

Selanjutnya sumber data penelitian 1) Sumber Data Primer adalah data yang diperoleh dari hasil observasi dan aktivitas siswa dan guru selama penelitian berlangsung di MI Datok Pattimang kecamatan suli kabupaten luwu. Sedangkan sumber data yang diperoleh ada dua tahap yang pertama data primer data yang berupa hasil pembelajaran siswa selama penelitian berlangsung, data yang diperoleh dari lapangan melalui wawancara

PiJIES: Pedagogik Journal of Islamic Elementary School 
terstruktur maupun tidak terstruktur terhadap informan yang berkompeten dan memiliki pengetahuan tentang penelitian ini. Agar dapat memperoleh sejumlah data primer, maka diperlukan sumber data dari obyek penelitian yang disebut kondisi tempat penelitian (Sugiyono, 2010: 215). Selanjutnya data yang kedua sumber dari data Sekunder, data yang diperoleh dari hasil pengambilan data-data di sekolah MI Datok Pattimang kec. Suli kab. Luwu dalam bentuk dokumen-dokumen yang telah ada serta hasil penelitian yang ditemukan peneliti secara langsung, data tersebut berupa dokumentasi penting menyangkut profil sekolah, dokumen kurikulum, petunjuk teknis pendidikan lainnya, serta perangkat pembelajaran setiap mata pelajaran, dan lain-lain (Burhan Bungin, 2017: 132).

Kemudian teknik pengumpulan data dalam penelitian ini penulis menggunakan teknik penelitian kepustakaan yaitu teknik pengumpulan data yang dilakukan berdasarkan literatur dengan jalan membaca buku-buku dan sumber-sumber lainnya yang ada hubungannya dengan penyusunan skripsi ini (Bungaran Antonius Simanjuntak, 2014: 12). Kedua teknik penelitian lapangan yaitu suatu jenis pengumpulan data yang melakukan penelitian langsung pada objek, penelitian yang menerapkan metode deskriptif kualitatif sebagai penarikan kesimpulan hasil penelitian (Fahmi Gunawan, 2018: 124). Kemudian analisis data dalam penelitian ini menyusun dan mengolah data yang diperoleh dilapangan kemudian menampilkan hasil kesimpulan penelitian dalam bentuk deskriptif (Sugiyono, 2010: 244). Menurut Hengky Wijaya, setelah tahap demi tahap terselesaiakan maka peneliti di arahkan untuk melakukan penarikan kesimpulan terhadap penelitiannya (Hengky Wijaya, 2018: 53). Dalam penelitian ini menggunakan reduksi data yang menyangkut pembelajaran berbasis religius dalam meningkatkan akhlak serta hasil belajar peserta didik pada MI Datok Pattimang Mario Kec. Ponrang Kab. Luwu. Tahapan kedua adalah melakukan penyajian data yang sudah disaring dan diorganisasikan secara keseluruhan dalam bentuk naratif deskriptif. Dalam penyajian data dilakukan interpretasi terhadap hasil data yang ditemukan, sehingga kesimpulan yang dirumuskan menjadi lebih objektif. Tahapan ketiga adalah melakukan penarikan kesimpulan, yaitu merumuskan kesimpulan setelah melakukan tahapan reduksi dan penyajian data secara induktif untuk menjawab rumusan masalah.

\section{HASIL PENELITIAN}

\section{Penerapan Pembelajaran Religius yang dilakukan Guru.}

Penerapan pembelajaran religius yang dilakukan guru di MI datok pattimang memberikan pengaruh positif. Hal ini dapat dibuktikan dengan meningkatnya proses pembelajaran PAI di MI datok pattimang baik itu Akhlak dan hasil belajarnya. Dimana seperti gambaran awal yang dikemukakan pada 
bab pendahuluan bahwa hasil belajar PAI peserta didik di MI Datok Pattimang semester II Tahun Pelajaran 2017/2018 rendah. Berdasarkan pembelajaran sebelum diterapkan pembelajaran religius yang dilakukan oleh peneliti di MI Datok Pattimang yaitu permasalahan pada observasi awal yang peneliti temukan berdasarkan pengamatan saat pembelajaran berlangsung, guru hanya memberikan kesempatan kepada peserta didik untuk membaca buku paket kemudian setelah itu guru menjelaskan materi tersebut dengan metode ceramah sehingga pembelajaran bersifat monoton dan tidak menarik. Akibatnya peserta didik banyak yang jenuh, bosan, acuh tak acuh dan mala banyak melakukan aktivitas lain yang akhirnya berdampak pada rendahnya hasil belajar peserta didik.

Selanjunya melakukan penerapan pembelajaran religius yang dilaksanakan sebanyak 4 kali pertemuan. Alokasi waktu setiap pertemuan adalah $(2 \times 35$ menit). Materi penelitian yang diajarkan yaitu materi Akidah Akhlak tentang keteladanan nabi Muhammad saw., dengan menggunakan pendekatan pembelajaran religius. Kemudian mengadakan refleksi yaitu membahas dan mengevaluasi kegiatan pembelajaran baru yang telah dilaksanakan. selanjutnya materi yang diajarkan yaitu MBTA tentang cara menghafal surah pendek. Langkah-langkah yang dilakukan relatif sama dengan perencanaan pembelajaran religius dengan mengadakan beberapa perbaikan dan penambahan terhadap kekurangan-kekurangan yang terjadi pada pemebelajaran sebelumnya.

Berdasarkan hasil penelitian bahwa penerapan pembelajaran religius yang dilakukan oleh guru dalam pembelajaran PAI pada peserta didik MI Datok Pattimang sudah sesuai dengan langkah-langkah pembelajaran dengan menerapkan pendeketan pembelajaran religius. Meskipun pada pembelajaran sebelumnya ditemukan beberapa kendala yang dilihat berdasarkan observasi. Sehingga pada pembelajaran selanjutnya dialakukan tindakan perbaiakan antaralain yaitu guru melakukan seluruh aktivitas berdasarkan langkahlangkah pemeblajaran religius secara optimal, pemberian reward kepada peserta didik yang mendapatkan hasil belajar terbaik serta menggunakan sumber belajar berupa gambar ilustrasi yang bertujuan agar menarik minat peseta didik dalam menganalisis masalah-maslalah yang berkaitan dengan materi. Dengan adanya perbaikan ini peserta didik lebih memahami lagi materi yang diajarkan, lebih kompak dalam kerja sama memecahkan masalah dan peserta didik lebih berani dalam mengungkapkan pendapatnya.

PiJIES: Pedagogik Journal of Islamic Elementary School 


\section{Pembelajaran Berbasis Pendekatan Religius di MI Datok Pattimang Mario Kec. Ponrang Kab. Luwu}

Sebagai sekolah berbasis keagamaan, Guru di MI Datok Pattimang dalam muatan pembelajaran apapun harus bisa mengkontekstualkan materimateri dengan dalil-dalil, baik itu hadits nabi, maupun dari kitab suci AlQur'an, karena dalam kitab suci Al-Qur'an itu adalah fakta-fakta kehidupan di dunia maupun di akhirat, namun saja fakta-fakta itu ada yang sudah terungkap dan ada yang belum terungkap. Pembelajaran demikian akan lebih efektif karena peserta didik sendiri yang mendapatkan pengetahuan. Pendekatan religius merupakan pendekatan yang memasukkan unsur-unsur religi dalam setiap muatan pembelajaran dan untuk menanamkan jiwa religi kepada dalam diri peserta didik. Guru selayaknya mampu menyisipkan pesan-pesan keagamaan untuk semua muatan pembelajaran baik umum maupun khusus. Penerapan nilai-nilai religi ini sangat penting untuk membentuk kepribadian seseorang dan nilai-nilai religius juga bisa meningkatkan kualitas proses pembelajaran bukan hanya sekedar materi saja yang kita dapat, tapi kita juga mendapatkan nilai-nilai religi untuk kehidupan sehari-hari kita, selain itu pula penerapan nilai-nilai religi ini berpengaruh pada akhlak seseorang. Jika seseorang tidak memiliki nilai-nilai keagamaan atau mengesampingkan nilainilai realigi maka seseorang itu tidak bisa mengendalikan ambisinya atau hawa nafsunya.

\section{Langkah-langkah Pembelajaran Berbasis Pendekatan Religius}

Dalam Meningkatkan Akhlak dan Prestasi Belajar Peserta Didik di MI Datok Pattimang Mario Kec. Ponrang Kab. Luwu antara lain a) Peneliti membuat kegiatan-kegiatan awal (pembuka) kegiatan pembelajaran di MI Datok Pattimang sesuai rencana pelaksanaan pembelajaran yang telah dibuat. b) kegiatan inti, mengaitkan pembelajaran dengan nilai religius dan kompetensi yang bersifat tambahan dari guru yang bertujuan mengampu muatan pembelajaran. agar guru dapat menentukan karakteristik dari setiap konsep materi pembelajaran, hal ini tentunya mempermudah guru mengembangkan materi dalam setiap proses pembelajaran. c) kegiatan penutup, guru dan peserta didik melakukan refleksi pembelajaran untuk memantau sejauh mana perkembangan siswa setelah melakukan pembelajaran.

\section{PEMBAHASAN}

\section{Pembelajaran Berbasis Pendekatan Religius}

Pembelajaran berbasis pendekatan religius pada dasarnya bukan hal baru di dalam dunia Pendidikan, salah satu konsekuensi dari pembelajaran religius yang dilaksanakan di MI Datok Pattimang adalah guru harus mampu mengaitkan tema-tema pembelajaran dengan nilai religius dalam mencapai 
tujuan utama pendidikan. Kemampuan mengaitkan tema dengan nilai-nilai religius, harus ditunjang dengan pengembangan wawasan guru-guru di MI Datok Pattimang, salah satunya adalah melalui pelatihan atau workshop pembelajaran. Namun hal yang tak kalah pentingnya adalah guru MI Datok Pattimang harus melakukan pembelajaran mandiri melalui bacaan-bacaan buku pendidikan terkait muatan pembelajaran yang diampunya.

Menurut Ibu Nur Asia dalam wawancara tetang pembelajaran religius

"Sebelum memulai inti pembelajaran biasanya saya bertanya dahulu kepada peserta didik saya, siapa yang tadi pagi telah melaksanakan shalat subuh? Bagi peserta didik yang melaksanakan tentu diberikan pujian, dan bagi yang tidak melaksanakan saya biasa bertanya, apakah mereka dibangunkan oleh orang tuanya untuk shalat atau tidak? Setelah itu saya biasa menceritakan kisah-kisah tentang anak saleh yang rajin beribadah dan membantu orang tuanya. Namun sebenarnya kegiatan-kegiatan seperti ini tentunya tidak setiap hari saya lakukan, dikarenakan harus mengejar materi pembelajaran pada pertemuan sebelumnya. Biasanya juga saya langsung menanyakan tugas -tugas yang telah saya berikan sebelumnya kepada mereka. Bagi yang belum mengerjakan tugasnya biasanya saya mencatat di buku mereka untuk diperlihatkan kepada orang tuanya di rumah."

Dari hasil wawancara dengan beberapa guru lainnya, mereka juga menyatakan pendapat yang sama bahwa nilai-nilai religius yang mereka laksanakan di dalam pembelajaran biasanya mereka laksanakan di awal pembelajaran yakni mengajak peserta didik untuk melaksanakan doa sebelum dimulainya pembelajaran. Adapun penyisipan nilai religius baik dalam bentuk menyampaikan kisah atau bercerita, tidak dilakukan setiap waktu kegiatan awal pembelajaran dikarenakan terbatasnya waktu yang digunakan untuk mencapai tujuan pembelajaran.

Kemudian pada kegiatan Inti, pembelajaran yang dilaksanakan di MI Datok Pattimang, harus menyesuaikan dengan Rencana Pelaksanaan Pembelajaran. Sebagaimana pendapat dari Ibu Hasmawati dalam wawancara penerapan pembelajaran religius:

“selalu kita menyisipkan nilai-nilai religius dalam pembelajaran, misalnya matematika, pembahasan pecahan misalnya, bagaimana caranya kita sisipkan nilai religius? Mungkin saja kalau kita kaitkan dengan tokoh Islam yang menemukan, atau umpamanya persamaan kita kaitkan dengan nilai-nilai kejujuran dan keadilan bahwa $1 / 4$ sama dengan 0,25 , tetapi habis waktu apa lagi kalau kita melakukan pembelajaran yang sifatnya umum keke agama, waktu pembelajaran hanya 2 x 35

PiJIES: Pedagogik Journal of Islamic Elementary School 
menit misalnya. Mana waktu kita harus menjelaskan operasional hitungannya, mana lagi waktu kita kasih tugas mereka, mana lagi waktu untuk memeriksa langsung tugasnya mereka. Jadi menurut saya di kegiatan inti, seperti pembelajaran matematika agak sukar di sisipkan. Berbeda ketika pembelajaran tentang PKn, ilmu pengetahuan sosial, atau ilmu pengetahuan alam, itu biasa saya agak gampang ji mengaitkan."

Mengaitkan pembelajaran dengan nilai religius memang membutuhkan skill dan kompetensi yang bersifat tambahan dari guru yang mengampu muatan pembelajaran. Jika guru dapat menentukan karakteristik dari setiap konsep materi pembelajaran, tentunya guru akan lebih mudah mengembangkannya dalam setiap proses pembelajaran. Guru dapat menciptakan desain pembelajaran dengan mengkombinasi nilai-nilai yang terkandung misalnya dalam konsep matematika. Sehingga, tujuan utama dari pendidikan karakter yang saat ini dilaksanakan di MI Datok Pattimang tidak hanya dituliskan sebagai syarat administratif saja, tapi benar-benar nilai karakter sikap peserta didik juga dapat terbangun dengan baik.

\section{Peningkatan Pembelajaran Akhlak}

Akhlak adalah wujud realisasi dan aktualisasi diri dari akidah seseorang (Dedi Wahyudi, 2017: 2). Akhlak merupakan gambaran dari keadaan yang ada didalam jiwa yang tertanam kukuh dimana prilaku menyandar padanya dengan gampang dan mudah tanpa membutuhkan pemikiran dan pertimbangan (Akhmad Sodiq, 2018: 2).

Berdasarkan hasil wawancara dengan salah satu guru pada Mata Pelajaran akidah akhlak di kelas IV MI Datok Pattimang, dari Bapak Andi Sakurdin dalam wawancara menyatakan (Andi Sakurdin, 15 Oktober 2018)

"Dari peningkatan akhlak siswa dapat dilihat dari tingkah laku dalam proses pembelajaran baik didalam kelas maupun diluar kelas, hal-hal yang Nampak dilihat contohnya adalah disiplin dalam waktu seperti datang kesekolah tidak terlambat, patuh sama guru, dan tidak mengganggu temanya belajar"

\section{Hasil Belajar Siswa}

Hasil belajar adalah merupakan maksimum yang diperoleh siswa dalam pembelajaran (Stefanus M. Marbun, 2018: 56). Oleh karena itu, maka kesuksesan atau tinggi rendahnya prestasi belajar yang dicapai seseorang amat tergantung dari kemampuan (pribadi) dan usaha atau aktivitas serta lingkungan belajarnya. Hal itu sejalan dengan pandangan teori-teori belajar yang dikemukakan sebelumnya. 
Berdasarkan hasil wawancara prestasi belajar siswa pada Mata Pelajaran akidah akhlak oleh Bapak Hidjir Ismail dalam wawancara menyatakan (Hidjir Ismail, 11 Oktober 2018).

"Setiap pendidik atau guru di MI Datok Pattimang sudah selayaknya mampu mengaitkan antara muatan pembelajaran yang dia ampu dengan hadis-hadis atau ayat-ayat suci al-Qur'an. Mereka kan guru di MI, apalagi sewaktu pertama kali diterima masuk mengajar, tentu mereka dites, baik mengajinya, hapalan surah-surah pendeknya, atau hadis-hadis hang mereka ketahui. Ini penting dalam pendidikan peserta didik MI Datok Pattimang yang notabene mereka adalah peserta didik madrasah. Tentu aneh, kalau gurunya tidak tau mengaji, atau tidak punya dasar pendidikan agama. Apalagi rata-rata guru di MI Datok Pattimang berasal dari STAIN/IAIN, saya yakin pengetahuan agama mereka pasti di atas rata-rata. Senada dengan Bapak Hidjir Ismail, menurut Ibu Hadijah dalam wawancara (Hadijah, 2 oktober 2018).

"Selama kurang lebih 15 tahun saya mengajar di MI Datok Pattimang, saya selalu menyisipkan pesan-pesan keagamaan di dalam pembelajaran yang saya lakukan. mudah menyisipkan pesan-pesan, karena yang saya mampu kan masih kelas 1, muatan pembelajarannya masih sangat sederhana. Apalagi sekarang sudah menggunakan K13 jadi mudah kita dalam menyisipkan pesanpesan keagamaan. Seperti contoh, membuang sampah sembarangan, saya juga biasa memberi contoh, dengan cerita atau kisah-kisah, bagaimana Rasulullah dalam menjaga kebersihan dirinya."

Tambahan wawancara Bersama Ibu Hasrah menyatakan bahwa (Hasrah, 30 oktober 2018).

"Ada peningkatan prestasi belajar siswa selama diterapkan pembelajaran berbasis pendekatan religius secara tidak langsung presetasi belajar siswa meningkat dikarenakan siswa betul-betul memperhatikan dan menyimak apa yang diajarkan, antara lain: baca tulis al-qur'an yang mulanya tidak lancar, setelah diterapkan pendekatan religius prestasi belajar siswa meningkat dan dapat melafalkan/membaca al-qur'an dengan baik".

Penerapan nilai-nilai religi ini sangat penting untuk membentuk kepribadian seseorang dan nilai-nilai religius juga bisa meningkatkan kualitas proses pembelajaran bukan hanya sekedar materi saja yang kita dapat, tapi kita juga mendapatkan nilai-nilai religi untuk kehidupan sehari-hari kita, selain itu pula penerapan nilai-nilai religi ini berpengaruh pada akhlak seseorang. Jika seseorang tidak memiliki nilai-nilai keagamaan atau mengesampingkan nilai-nilai realigi maka seseorang itu tidak bisa mengendalikan ambisinya atau hawa nafsunya.

PiJIES: Pedagogik Journal of Islamic Elementary School 
Kendala dalam Pembelajaran Berbasis Pendekatan Religius dalam Meningkatkan Akhlak dan Prestasi Belajar Peserta Didik di MI Datok Pattimang Mario Kec. Ponrang Kab. Luwu. 1) Peserta Didik, Pendidikan merupakan tanggung jawab bersama antara sekolah (guru), orang tua peserta didik, masyarakat, dan pemerintah. Dengan demikian, semua pihak yang terkait harus senantiasa menjalin hubungan kerjasama dan interaksi dalam rangka menciptakan kondisi belajar yang sehat dan kondusif bagi para peserta didik. Interaksi antara sekolah (Guru MI Datok Pattimang) dengan orang tua tentu akan mendorong peserta didik untuk senantiasa melaksanakan tugasnya sebagai pelajar, yakni belajar dengan tekun dan bersemangat. Hubungan timbal balik antara orang tua dan guru yang bernilai informasi tentang situasi dan kondisi setiap peserta didik juga akan melahirkan suatu bentuk kerjasama yang dapat meningkatkan aktivitas belajar dan berdampak baik bagi psikologis peserta didik baik di sekolah maupun di rumah. 2) Pendidik, Upaya peningkatan kompetensi guru di MI Datok Pattimang harus dilakukan oleh semua pihak, baik dari guru maupun dari pihak yayasan pendidikan. Idealnya, ada dua upaya peningkatan kompetensi guru yang sangat mempengaruhi, yaitu upaya yang dilakukan guru itu sendiri dan upaya yang dilakukan oleh lembaga pendidikan yang bersangkutan.

\section{PENUTUP}

Adapun dari hasil analisis data penelitian serta rumusan masalah dapat disimpulkan antara lain 1) Pembelajaran berbasis pendekatan religius di MI Datok Pattimang Mario Kec. Ponrang Kab. Luwu dilakukan dengan mengaitkan dan mengintegrasikan nilai-nilai religius dalam proses pembelajaran demi tercapainya tujuan pembelajaran pada tiap-tiap muatan pembelajaran. 2) Langkah-langkah pembelajaran berbasis pendekatan religius dalam meningkatkan akhlak dan prestasi belajar peserta didik di MI Datok Pattimang Mario Kec. Ponrang Kab. Luwu dilakukan dengan menyisipkan nilai religius dimulai dengan kegiatan awal, kegiatan inti, dan kegiatan penutup pembelajaran berupa kegiatan berdoa, bercerita, dan tanya jawab dengan peserta didik. 3) Kendala pembelajaran berbasis pendekatan religius dalam meningkatkan akhlak dan prestasi belajar peserta didik di MI Datok Pattimang Mario Kec. Ponrang Kab. Luwu berasal dari peserta didik, pendidik dan sarana prasana pendukung proses pembelajaran. 


\section{DAFTAR PUSTAKA}

Aeni, Ani Nur. 2014. Pendidikan Karakter untuk Mahasiswa PGSD, Bandung: Uni Press.

Anwar, Muhammad, 2018. Menjadi Guru Profesional, Jakarta: Pernada Media.

Bungin, Burhan. 2017. Metodologi Penelitian Kualitatif, Jakarta: Kencana.

Dalimunthe, Sehat Sultoni. 2016. Filsafat Pendidikan Akhlak, Yogyakarta: Budi Utama,.

Darnia. (2019). Efektivitas Pemberian Penguatan Berkearifan Lokal Terhadap Motivasi Belajar Ilmu Pengetahuan Sosial (IPS) Siswa Di Kelas III SD Islam Datok Sulaiman Bagian Putri Palopo. Pedagogik Journal of Islamic Elementary School, 2(1), 41-54.

Departemen Agama R.I., 2015. Al-Qur'an dan Terjemahnya, Bandung: Darus Sunnah.

Evra et.al., 2018. Senarai Penelitian Islam Kontemporer Tinjauan Multicultural, Yogyakarta: Budi Utama, .

Firdaus, Fakhry Zamzam. 2018. Aplikasi Metodologi Penelitian, Yogyakarta: Budi Utama.

Fitri, Agus Zaenal. 2012. Pendidikan Karakter Berbasis Nilai dan Etika di Sekolah, Jakarta: Pustaka Pena.

Gunawan, Fahmi. 2018. Senarai Penelitian, Yogyakarta: Budi Utama.

Izzan, Akhmad, et.al., 2012. Membangun Guru Berkarakter, Bandung: Humaniora.

Marbun, Stefanus M. 2018. Psikologi Pendidikan, Ponorogo, Uwais Inspirasi Indonesia,

Naim, Ngainun, Achmad Sauqi. 2011. Pendidikan Multikultural Konsep dan Aplikasi, Yogyakarta: Arr Ruzz Media.

Neolaka, Amos, Grace Amalia A. Neolaka. 2018. Landasan Pendidikan, Jakarta: Kencana.

Rustan, E., Hanifah, N., \& Kanro, B. (2018). De-radicalization in the Implementation of Islamic Education Curriculum in SMA Masamba South Sulawesi. Dinamika Ilmu, 18(2), 271-283. https://doi.org/10.21093/di.v18i2.1338

Thaha, H., \& Rustan, E. (2017). Orientasi Religiusitas dan Efikasi Diri dalam Hubungannya dengan Kebermaknaan Pendidikan Agama Islam pada Mahasiswa IAIN Palopo. Jurnal Studi Agama Dan Masyarakat, 13(2), 163179. https://doi.org/10.23971/jsam.v13i2.551

Sapsuha, M. Tahir. 2013. Pendidikan Pasca Konflik: Pendidikan Multikultural Berbasis Konseling Budaya Masyarakat Maluku Utara, Yogyakarta: LKIS Printing Cemerlang.

Simanjuntak, Bungaran Antonius. 2014. Metode Penelitian Sosial, Jakarta : Yayasan Pustaka Obor.

PiJIES: Pedagogik Journal of Islamic Elementary School 
Sodiq, Akhmad. 2018. Properti Character Building, Jakarta: Kencana.

Sugiyono. 2010. Metode Penelitian Kuantitatif, Kualitatif dan R\&D, Bandung: Alfabeta.

Syarbini, Amirulloh. 2014. Model Penelitian Karakter dalam Keluarga, Jakarta: Gramedia.

Thalib, A. (2018). Pendekatan Keterampilan Proses Dalam Meningkatkan Ha sil Belajar Bahasa Indonesia. Pedagogik Journal of Islamic Elementary School, 1(1), 23-36.

Undang-Undang RI. 2012. Tentang Sistem Pendidikan Nasional, Bandung: Citra Umbara.

Wahyudi, Dedi. 2017. Pengantar Akidah Akhlak dan Pembelajaran, Yogyakarta: Lintas Rasi Aksara Books.

Wijaya, Hengki. 2018. Analisis Data Kualitatif, Makassar: Sekolah Tinggi Theolegia Jeffray. 
172 | Muhamad Arfah

----halaman ini sengaja dikosongkan---

PiJIES: Pedagogik Journal of Islamic Elementary School 